\title{
The State of the Art in Happiness Advice; Can We Escape the Dodo-Verdict?
}

\section{Sonja Lyubomirsky: The How of Happiness; A New Approach to Getting the Life You Want, Penguin Books, London, 2008, 366 p, ISBN 978-0-14-311495-6}

\section{Ad Bergsma}

Published online: 8 April 2010

(C) The Author(s) 2010. This article is published with open access at Springerlink.com

Sonja Lyubomirsky is one of the leading happiness researchers in the world and her selfhelp book The How of Happiness has received wide acclaim from important scholars in positive psychology. ${ }^{1}$ Mihaly Csikszentmihalyi writes that Lyubomirsky 'provides practical suggestions for improving one's life that are easy to follow'. He adds that her book is a 'wonderful addition to everyone's library'. Martin Seligman: 'The right place to look for science-based advice on How To Become Happier.'

Daniel Gilbert is even more outspoken: 'Everyone has an opinion about happiness, and unfortunately, many of them write books. Finally we have a self-help book from a reputable scientist whose advice is based on the best experimental data. Charlatans, pundits, and new-age gurus should be worried and the rest of us should be grateful. The How of Happiness is smart, fun, and interesting - and unlike almost every other book on the same shelf, it also happens to be true.'

If we take the remark of Gilbert literally, we can call the The How of Happiness the new bible of popular positive psychology and say 'amen, praise the scientist'. I intend to be a little more cynical. I will regard Lyubomirsky's book as the state of the art in popular advice about happiness, and try to assess how far we have come. In general I agree that Lyubomirsky's book is about as good as it gets, but still it leaves a lot to be desired.

\section{A New Standard}

The How of Happiness has set a new standard in happiness advice, as far I know it, mainly because Lyubomirsky has made three important contributions. The first is that she has customized the book for different readers. She acknowledges that different people may need different happiness strategies and she offers a provisional instrument to make a selection. The second contribution is that she stresses the importance of sustaining higher

${ }_{1}$ Positive reviews of The how of happiness are collected in the first pages of the book and on the website: http://chass.ucr.edu/faculty_book/lyubomirsky/praise.html.

A. Bergsma $(\square)$

Erasmus University, Rotterdam, The Netherlands

e-mail: bergsma@fsw.eur.nl 
well-being. Focusing on positive emotions, variation and timing of positive activities, social support, effort and commitment could help readers to make a lasting change in their lives. Lyubomirsky also mentions habit formation: 'Because such activities as looking on the bright side, savoring the moment, practicing forgiveness, and striving for important life goals make a difference in your happiness, it is certainly a good idea to make a habit of doing them' (p. 281).

The third important contribution of The How of Happiness is that it is evidence-based for a large part. There is empirical data available for all the happiness strategies offered that shows that they can raise happiness. It is difficult to underestimate the importance of this contribution. The Journal of Happiness Studies compiled a special issue on happiness advice, looking at world famous thinkers such as Confucius, Buddha, Lao Tse, Epicurus and Schopenhauer and concluded on the basis of empirical data that in some respects their advice was completely wrong (Bergsma 2008a). Lyubomirsky has shown the self-discipline to avoid such blatant mistakes. On the other side, I do not believe that the fact that she used available evidence implies that she is right in all respects, nor that her book will have an optimal therapeutic effect. The first reason to doubt is that although many of the recommendations are evidence-based, this is not true for the whole of the work. In essence it remains an untested self-help manuscript. The distinction is important, because Rosen et al. (2003) describe that well-intended and educated efforts to improve self-help manuals can, and sometimes do, have unintended negative consequences. We need to test the effects of Lyubomirsky's book empirically to be sure.

\section{The Diagnostic Self-Test}

Let me consider the diagnostic self-test that helps to select happiness exercises, I mentioned earlier as an example. The test is included, because people must select a strategy to raise their happiness that suits their characteristics. However, the test she presents is only used in empirical research to compare two happiness strategies: expressing gratitude and cultivating optimism. The test was not used to select one strategy out of all twelve happiness strategies Lyubomirsky discerns.

A limitation of the self-test is that it is based on self-knowledge. Readers are invited to estimate how well they would like a particular activity. This is tricky, because some people may be unhappy because they lack the self-knowledge to choose a course in life that suits them best. Still, Lyubomirsky urges readers to use their self-knowledge to escape this vicious circle. My guess is that this strategy would indeed help some people to get a better grasp of how they can try to be happier, but she does ask a lot of the self-direction of her readers. Perhaps the people who need tailored happiness advice the most, are least able to profit from the diagnostic self-test. The self-test does not meet the standard that Lyubomirsky describes in the first pages in the book, when she remarks that only double-blind experimentation offers the kind of knowledge to be trusted enough to decide whether a claim is true.

\section{Evidence is Necessary, But Not Enough}

In addition to that one can wonder how effective any evidence-based approach, like the one advocated by Lyubomirsky, will be. Since the effects of self-help have not been studied intensively enough to report conclusions, I will use research of the effects of psychotherapy as an analogy. 
It is clear that some psychological treatments are harmful, and should not be used anymore (Lilienfield 2007) The How of Happiness is flawless in this respect. Still, it is generally agreed upon that evidence-based treatment methods have yielded limited results in psychotherapy. Although the psychodynamic, humanistic or behavioral schools of psychotherapy have vastly different investments in scientific effect studies, they all tend to yield quite similar results. Luborsky et al. (1975) famously suggested to use the verdict of the Dodo in Alice in Wonderland: 'Everyone has won and all must have prizes.'

Almost everyone wins, because the effect of psychotherapy does not only depend on the specific treatment, but also on common factors, like the personal resources and life circumstances of the client (which explain $40 \%$ of outcome variance), the emotionally charged relationship with the therapist (30\%) and placebo, hope and expectancy (15\%). The specific techniques and models of the treatment may explain as little $15 \%$ of treatment variance (Hubble and Miller 2004).

We can tentatively extrapolate these findings to self-help. It seems reasonable to assume that readers are more likely to profit from a self-help book like The How of Happiness if they have better personal resources, such as hope and expectancy, reading skills, an understanding partner, and the stamina to keep going. The public image of the writer and his or her style of writing may also be of importance. All these factors are independent of the evidence base of specific recommendations. Perhaps the recommendations as such, and the related happiness exercises, are only of minor importance for the impact of happiness self-help (Bergsma 2008b).

Therefore I would not dare to bet that Lyubomirskys book will be more effective than, for example, Michael Fordyce's happiness program, made at a time when happiness research was still a marginal activity $(1977,1983)$. I note that Fordyce's happiness program was tested as a whole, whereas this is not the case for Lyubomirsky's book yet, as far as I know. This leads me to the conclusion that Lyubomirsky can use a wealth of data that was not available to Fordyce, but it is uncertain whether her book will escape the dodo verdict. Only experimentation may provide us with an answer.

There is even room for doubt whether the New Age self-help books, that Gilbert so despises, are less effective than Lyubomirsky's book. There are two reasons that come to mind for this seemingly nasty remark. The first is that the happiness exercises that Lyubomirsky offers to the readers are not surprising. It is the kind of advice that your grandmother would also offer. In other words the strategies offered are not that different from what common sense suggests and they are somewhat corny, as Lyubomirsky herself keeps repeating. The science of happiness was scooped in many of its ideas by many ancients thinkers who were good psychologists in the absence of any formal data (Haidt 2006). For many of the New Age thinkers the same is true. Berg (2008) has shown that many of the happiness suggestions in New Age books are in line with existing evidence.

The second reason may be that New Age thinkers might have better toolkits to change the way people view the world, something that is undoubtedly a major factor in happiness. I will give one example. Lyubomirsky explains that enhancing beauty is not a good way to stimulate happiness. Happy people are no better looking than people with less positive emotions. Still happy people do consider themselves to be more attractive. So the reader is left with the suggestion to try to see him- or her-self as beautiful, in the full knowledge this is an illusion. Seeing yourself as beautiful is just a trick to make you feel better about yourself.

New Age philosophers are not bound by the limits of the scientific method. They can and do think of very different ways to help us think of the world and ourselves as beautiful. There might be an unspoiled inner child in each of us, a world that offers you everything that you need if you want it enough (the secret), an afterlife that will be better, former lives 
that explain all our shortcomings, a supporting cosmic energy or anything else you might hope for. Lyubomirsky's advice is limited by the scientific method, but I do not know if this yields superior results for readers, as Gilbert suggests. In the absence of any experimentation I think it would be more appropriate to assume a modest position about what science has to offer in pursuing happiness. I hope that somebody will empirically assess if Lyubomirsky's book has superior results to a beloved new age book.

\section{Are Top Scientists the Best Self-Help Authors?}

I have discussed the more theoretical issues about the possibilities of using science in happiness advice, but let us now turn our attention to the influence of being a scientist. Lyubomirsky is praised by Csikszentmihalyi for using elegant prose that is accessible for anyone. I agree with him that the book is well written in general, but I also feel that the text seriously suffers from the expertise of Lyubomirsky. She seems to be so used to writing for scientific magazines and to communicating with peers and students that she sometimes fails to notice that she uses words that require a lot of background knowledge of the readers. For example she manages to squeeze the words 'double-blind experiment', 'randomly assigned participants' and 'control group' into one sentence, all without any explanation. Such language will hinder any non-academic readers. Martinez et al. (2008) have shown that it is a general problem in self-help manuals that a significant part of the population does not understand the instructions. My guess is that this is also true for The How of Happiness. Being a world class scientist may improve the quality of the message, but in this case it also hinders the author's adapting to the level of a lay audience.

\section{A Bad Marriage: A Circumstance or Intentional Activity?}

I also suspect some miscommunication between the scientist Lyubomirsky and the lay audience in the heart of the book, the 40 percent thesis. She states that 50 percent of our happiness is determined by our genes, and 10 percent by the circumstances. This leaves a 'startling, and startlingly underdeveloped 40 percent of our capacity for happiness within our power to change.' (bookcover).This line of thinking is startlingly difficult. What does it mean if forty percent of my happiness is the result of intentional activity?

This 40 percent thesis is also bound to lead to misunderstandings. Lyubomirsky repeatedly states that the circumstances of life are unimportant for our well-being, and that we should change the way we look at and deal with the world; but the word 'circumstances' may mean something totally different in the data pattern than in an individual life. For example, if we collect data we ask subjects whether they are married. After the data collection we conclude that being single or married does not enable us to explain much of somebody's happiness, and marriage is put in the 10 percent section 'circumstances'. How happy you are with your marriage does matter much more, and this is put in the forty percent section of 'conscious behavior'.

Lyubomirsky advises people to develop a positive view on their marriage and to put effort in the relationship. This seems reasonable. Yet for an individual life things may look quite different. Any individual would agree that it makes a huge difference in the circumstances of their lives, whether they are married to a Mother Theresa or a Mike Tyson in a foul mood, whereas for the data pattern both have to deal with the circumstances 'being married'. If individuals with a violent and abusing partner take the message about the forty 
percent thesis literally, they should decide to think lovely thoughts about their partners and put more effort in their relationship, because the circumstances of life are rather insignificant. In practice readers will probably not make this mistake, but the reader is left in the dark regarding the question what exactly are circumstances, and when it is better to change or to accept them.

\section{The Ethics of Self-Help}

In 1978 a taskforce of the American Psychological Association with Gerald M. Rosen as a chair produced a report on self-help therapies (Rosen 2004). The taskforce paraphrased the APA ethical standards for psychologists for self-help authors. They write: Public statements, announcements, and promotional activities pertaining to a commercially published self-help therapy should be informative. Sensationalism is to be avoided in such statements. The limitations, as well as the benefits of a self-help therapy should be clearly stated.

It is questionable if Lyubomirsky completely lives up to this recommendation. Publishing the exalted praise by Gilbert that she has written a book that is true and way better than almost any other book on the subject, can be considered as a form of sensationalism. If life was so simple that we only need an expert opinion to decide what is true, we could do without science.

The reason I mention this is not to be overly stern. I personally would probably use any praise for my work to sell it, how exaggerated it may be: but I do think that we should ask what the effect it will have on the reader. Lyubomirsky states that you can get the life you want, that going through her book is the most rewarding thing that you may ever do, that her advice is based on science, and that it is up to the reader to become happier. This will probably have a positive effect on most readers. Some will have more confidence that they can improve and, as a result, put more effort in changing their lives for the better. The message helps them to achieve the internal locus of control that is needed to really give the exercises a try.

Still, I think some readers will not feel great after reading the book, even after sincerely trying the exercises. They will not be able to lift their spirits and perhaps they will not blame the silly self-help book they have read, but themselves. Such internal attributions in combination with failure can be harmful, and they could lower happiness. The resulting thoughts may be something like this: 'Life could be better if I only would be clever enough to improve my life with the help of scientific exercises. There must be something seriously wrong with $m e$.' The readers mental standard of how life could be is raised, but perhaps their positive moods remain scarce, and as a result the everyday misery may be harder to bear. Such disappointment may prevent a person from trying to find another way to raise happiness. Of course, this is speculation, but in absence of data we will never know for sure.

\section{Advice or Feedback?}

The positive message may also have negative side-effects in another way. In an interview with a Dutch newspaper Ruut Veenhoven suggested that it might be better for some people not to teach them how they can increase their happiness, but to give them feedback on how they are doing (Bergsma in press). If you are a one-legged, neurotic widow and you rate your happiness with a six on a scale of ten, then maybe the best message is that you are fine as you are. The widow's circumstances and her personality (genes) will probably not allow 
a further raise in happiness, and instead of reading a self-help book that will not work miracles, she might do something with her life that is more fruitful for herself or for somebody else. If we want to raise the quality of happiness advice we will also need to learn who should not be bothered with it. I would certainly recommend Lyubomirsky's book to people who are looking for a self-help book on happiness, but I would also tell them to be aware of potential pitfalls, even though they may be insignificant for most.

Open Access This article is distributed under the terms of the Creative Commons Attribution Noncommercial License which permits any noncommercial use, distribution, and reproduction in any medium, provided the original author(s) and source are credited.

\section{References}

Berg, M. C. (2008). New age advice: Ticket to happiness? Journal of Happiness Studies, 9, 361-377.

Bergsma, A. (2008a). Advice of the wise; Introduction to the special issue on advice for a happy life. Journal of Happiness Studies, 9, 331-340.

Bergsma, A. (2008b). Do self-help books help? Journal of Happiness Studies, 9, 341-360.

Bergsma, A. (in press) Positieve psychologie: haarlemmerolie of wondermiddel? (The merits of positive psychology). Psychologie en Gezondheid.

Fordyce, M. W. (1977). Development of a program to increase personal happiness. Journal of Counseling Psychology, 24, 511-520.

Fordyce, M. W. (1983). A program to increase happiness: Further studies. Journal of Counseling Psychology, 30, 483-498.

Haidt, J. (2006). The happiness hypothesis; Putting ancient wisdom and philosophy to the test of modern science. New York: Basic Books.

Hubble, M. A., \& Miller, S. D. (2004). The client: Psychotherapy's missing link for promoting a positive psychology. In P. A. Linley \& S. Joseph (Eds.), Positive psychology in practice. Hoboken, NJ: Wiley.

Lilienfield, S. O. (2007). Psychological treatments that cause harm. Perspectives on Psychological Science, 2, 53-70.

Luborsky, L., Singer, B., \& Luborsky, L. (1975). Comparative studies of psychotherapy. Archives of General Psychiatry, 32, 995-1008.

Martinez, R., Whitfield, G., Dafters, R., \& Williams, C. (2008). Can people read self-help manuals for depression? A challenge for the stepped care model and book prescription schemes. Behavioural and Cognitive Psychotherapy, 36, 89-97.

Rosen, G. M. (2004). Remembering the 1978 and 1990 task forces on self-help therapies. Journal of Clinical Psychology, 60(1), 111-113.

Rosen, G., Glasgow, R., \& Moore, T. (2003). Self-help therapy: The science and business of giving psychology away. In S. Lilienfed, S. Lynn, \& J. Lohr (Eds.), Science and pseudoscience in clinical psychology (pp. 399-424). New York: Guilford Press. 